原著

強大音刺激時のラット脳幹内 c-fos 陽性細胞発現様式

一特に前庭神経核内の分布について一

張 瑞麗

\title{
Expression of c-fos Like Protein in the Rat Brainstem Following Intense Sound Stimulation
}

\author{
RuiLi Zhang \\ Department of Otolaryngology, Toyama Medical and Pharmaceutical University
}

In this study the induction of c-fos, a protein product of proto-oncogene $c$-fos, was immunohistochemically examined in rat caudal brainstems in response to intense sound. One $\mathrm{kHz}$ of pure tone stimulation at 110 and $130 \mathrm{~dB}$ SPL was applied for 60 mins. In comparison with non-stimulated control rats, the brainstem of the soundstimulated rats showed c-fos protein in both the inside of the cochlear nucleus and the vestibular nucleus. In the vestibular nucleus, sound stimulation at $130 \mathrm{~dB}$ SPL led to widespread c-fos labeling in the medial, spinal and lateral vestibular nucleus compared with that at $110 \mathrm{~dB}$ SPL. The distribution of the primary vestibular afferent fiber projected from the saccule to the vestibular nucleus overlaped that of $c$-fos labeling neurons at $130 \mathrm{~dB}$ SPL, suggesting that the saccule is the origin of the c-fos labeling vestibular neurons produced in response to the intense sound.

Key words: rat, brainstem, c-fos, sound, gene expression

\section{はじめに}

強大音によりめまいや眼振が誘発されること は，1924年に Tullio1)が鳵の外側半規管に瘦孔を 作製して報告して以来 Tullio 現象として広く知 られている。この現象は, 内耳梅毒2, メニエー ル病 ${ }^{3)}$, 外リンパ㿉 ${ }^{4)}$ などの内耳疾患の他, 健常 人5)でもジェット機近傍の爆音で同様の症状が起 きることが報告されている。

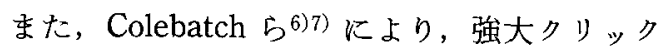
音を用い胸鎖乳突筋で記録される短潜時の誘発筋 電位は前庭神経切断術後に消失することから前庭

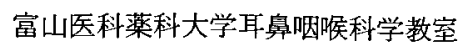

系の反応と考光られ，新しい前庭機能検查法とし て臨床応用が期待されている。

末梢前庭器のうち球形褧は, 発生学的に蝸牛之 同一の原基をもつため, 聴覚機能をもつと考元ら れている8)。動物実験での球形囊神経応答の特徽 を蝸牛神経と比較してみると, 蝸牛神経よりも短 潜時, 高閾值で, 特徵周波数が低いことが球形裂 神経の特徵であると報告されている9 〜11)。ト 前庭誘発筋電位でも同様の特徵があるため7), こ のよらな強大音に対する前庭性反応の起源として は球形䡛が最有力視されている。

一方，前庭神経核（VN: 表 1 略語参照）のう ち外側前庭神経核 (LAV), 内側前庭神経核 (MV), 
表 1 略語

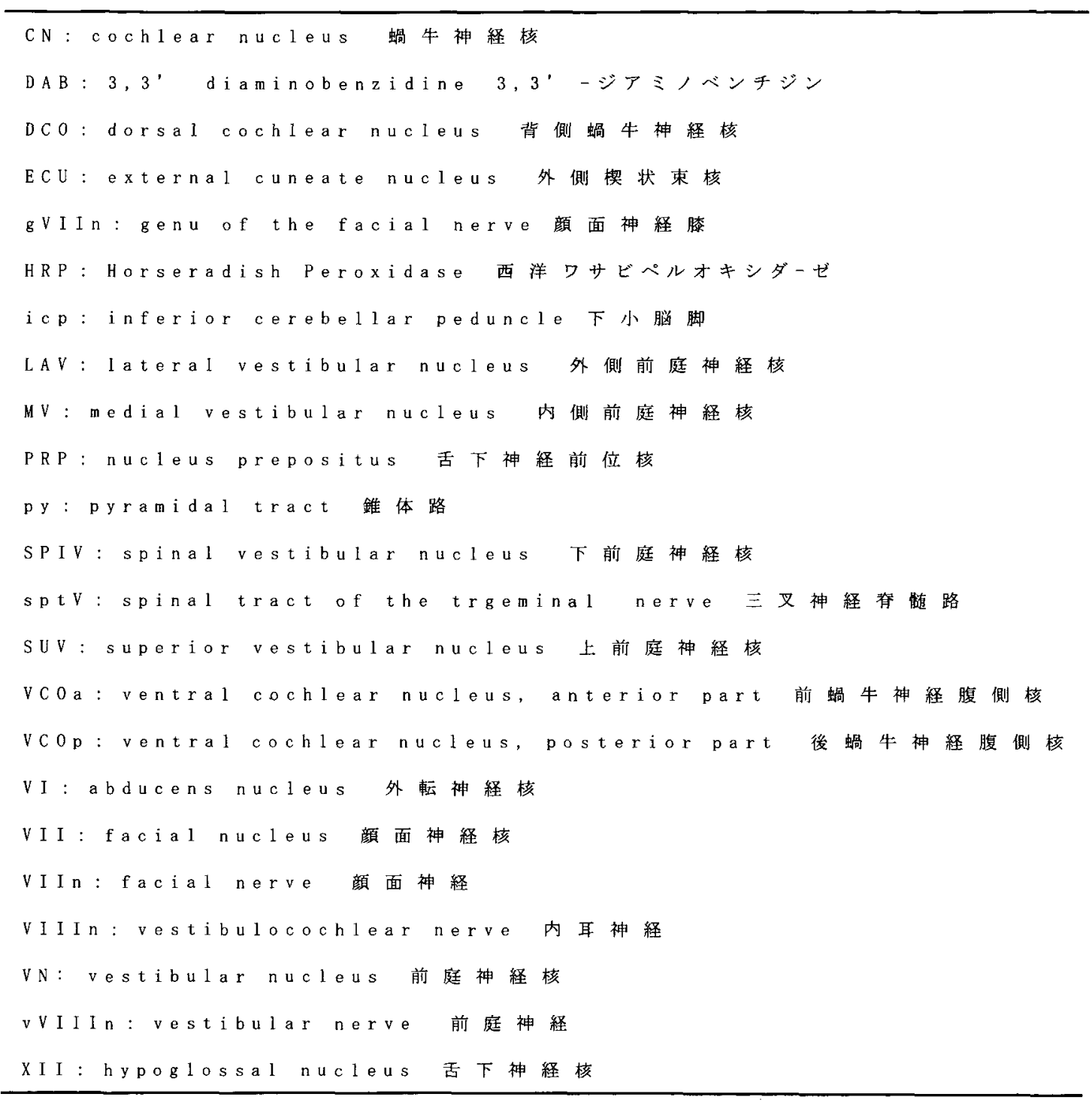

下前庭神経核 (SPIV) に执いて，これをで強大 音に応答するニューロンが数個ずつ記録されてい るが12)，サンプル数が少ないためにそれぞれの亜 核内での局在の特徵については明らかでない。そ のため, 強大音応答二ューロンの前庭神経核内の

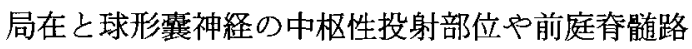
の起始核分布との関係についての検討は十分に行 われていない。これらの点を明らかにすること は, 音刺激に対する前庭反応の神経経路を解明す る上で重要であり, 臨床診断学的にも有用性が高
いと考完られる。

ところで, 癌ウイルス遺伝子のプロトタイプと して発見された癌原遺伝子 c-fos は正常細胞に拉 いては細胞の増殖, 分化の調節に関与して特り, 種々の刺激に反応して神経細胞内に短時間で発現 することから最初期遺层子 (immediate-early gene）とる呼ばれ，細胞活動の指標となることが 報告されている13)。このc-fos マッピング法によ り, 刺激に応答した c-fos 陽性細胞の存在部位か ら，刺激に関与する神経回路を調べることができ 
各14) 15)

本研究では，脳幹に括いて強大音に応答する神 経細胞の局在を調べるため，ラットに強大音を負 荷した際に発現する c-fos を免疫組織化学的方法 により染色, c-fos 陽性細胞の局在を蝸牛神経核 (CN) 括よび前庭神経核で検討した。

\section{対象亡方法}

\section{1. 対 象}

実験には Preyer 反射16)17) 陽性のウィスター系 ラット（雄：体重 250-300 g）を11匹用いた。

2 . 音刺激

他覚的聴力検査用信号発生器 Model DA-502A (Dana JAPAN 社製) を用いて発生した $1 \mathrm{kHz}$ の 純音をパワーアンプ (SONY TA-N 330-ES) にて 増幅して刺激音とした。スピーカー（JBL 社製 Model 2441）はラットを放置する箱から $30 \mathrm{~cm}$ 離して設置した。音压校正には，騒音計（RION 社製 Sound Level Meter NA-20) を用い，スピー カ一前方 $30 \mathrm{~cm}$ に騒音計を置き，測定された音 圧 $(\mathrm{dB})$ レベルを $\mathrm{dB} \mathrm{SPL}$ と表示した。本夷験で は, $110 \mathrm{~dB} と 130 \mathrm{~dB} \mathrm{SPL}$ の 2 種類のレベルの 音刺激を使用した。

\section{3 . 実験条件}

音刺激は無麻酔で, 音, 光, 振動などの外的刺 激が遮断された環境で行った。ラットは遮光され た防音室内に設置された透明の箱の中 $(25 \mathrm{~cm}$ 〈長〉 $\times 17 \mathrm{~cm}\langle$ 幅〉 $\times 17 \mathrm{~cm}\langle$ 高〉) で自由に行動で きるようにした。

音刺激条件によりラットは 3 群に分けられた。 I 群 $(n=4)$ は対照群で, 音刺激を与克ず, 先に 述べた防音室内の透明箱の中にラットを60分間放

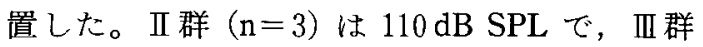
$(\mathrm{n}=4)$ は $130 \mathrm{~dB}$ SPL で音刺激を60分間負荷 L た。

4.固定標本作製特よび免疫組織化学

固定標本の作製拈よび免疫組織化学は, Hamba ら ${ }^{18)}$ の方法に從った。音刺激終了後, 5 分以 内にネンブタルを腹腔内注射 $(50 \mathrm{mg} / \mathrm{kg})$ L, 心 臓より生理食塩水（室温）で $300 \mathrm{ml}$ 灌流した後, $4 \%$ パラホムアルデヒド (PFA) を含んだ 0.1 $\mathrm{M}$ リン酸パフォ(PB, pH 7.4, 4 C) $400 \mathrm{ml}$ にて 灌流固定し，脳幹を摘出した。摘出脳幹は，同じ 固定液中に 12 時間浸漬 $\left(4^{\circ} \mathrm{C}\right)$ して固定した。そ

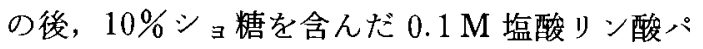

フォ $\left(\mathrm{PBS}, 4^{\circ} \mathrm{C}\right)$ に24時間, $20 \%$ 同剤で 24 時間, および30\%同剂で48時間浸漬することで固定液を 洗浄し，クライオスタット（ライヘルトフリゴ カット $2800 \mathrm{~N})$ を用いて，20 $\mu \mathrm{m}$ の連続冠状断 凍結切片を作製し，スライドグラス上で60分間乾 燥させた。

c-fos 陽性細胞の免疫組織化学染色は, VECTASTAIN Elite ABC KIT (VECTOR 社製) に よる $\mathrm{ABC}$ 法 ${ }^{19)}$ を用いた。乾燥させた切片は 0.01 M PBS で洗浄後, c-fos 陽性細胞の非特異的結合 のブロックを行らために， $0.2 \%$ triton-X100を 含む $0.01 \mathrm{M}$ PBS (PBST) のヤギ正常血清によ る $1 \%$ に希釈した液を滴下し 3 時間反応させた。 一次抗体はウサギ抗ヒトポリクローナル抗体 (Oncogene science 社製, c-fos, Ab-2) $0.01 \mathrm{M}$ PBST 400倍希釈液にて $4{ }^{\circ} \mathrm{C} て ゙ 72$ 時間反応させ た。その後, 0.1 M PBS にて洗浄し，二次抗体 であるビオチン化ヤギ抗ウサギ IgGを 8 時間, アビシンンビオチン化 HRPを14時間反応させた。

酵素組織化学染色 HRP には，3,3'diaminobenzidine によるDAB 法を行った。0.05\% DAB， $0.01 \% \mathrm{H}_{2} \mathrm{O}_{2}$ を混和した $0.05 \mathrm{M}$ tris- $\mathrm{HCl}$ 緩衝液 (pH 7.6) にて室温20分間で発色させた。

5. c-fos 陽性細胞の判定

各ラットの冠状断脳幹切片は光学顕微鏡的に観 察し，描画装置（オリンパス社製 Model BH2DA）を使用して描画した後に c-fos 陽性細胞の 位置を記入した。各切片から, 脳幹の立体構造を 再構築し，前庭神経核を12等分した前額断の図を 作製した。c-fos 陽性細胞の判定は200倍の倍率で 明確な DAB 反応を示した細胞のみを陽性とした （図 1 ）。この方法により, ラットの脳幹容積の個 体差に関わらず，脳幹尾側部の特定部位を番号で 示すことが可能となった。たと兄ば，背側蝸牛神 経核 (DCO) 恃図 2 の切片 7-10, 上前庭神経核 (SUV) は同切片10-12, LAV は同切片 9-11, MV は同切片 1-12, SPIV は同切片 1-9 で示さ れる。脳幹の区分と命名は Swanson 脳図譜 ${ }^{20)} に$ 従った（図 2 )。

\section{6 . 統計処理}

本研究では, 前庭神経核の MV, LAV, SPIV 牤よび蝸牛神経核の DCO K执いて，観察された c-fos 陽性細胞数の群閐の此較を Krnskal-Wallis 検定を用いて行った。 

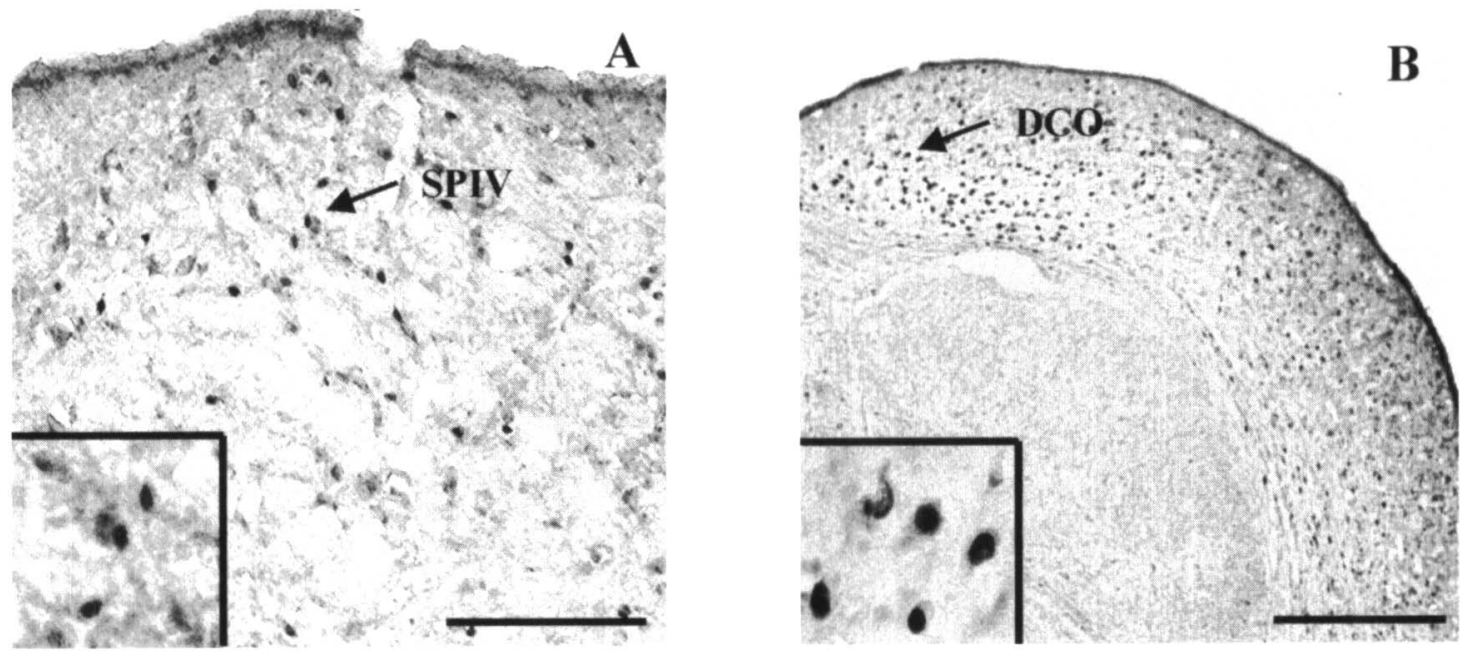

図 1 c-fos 陽性細胞の明視野顕凯鏡写真

A: 下前庭神経核 (SPIV), B: 背側蝸牛神経核 (DCO), 枠内は矢印で示す陽性細胞の拡大写真。校正; A 右下：0.2 mm, B 右下: $0.25 \mathrm{~mm}, \mathrm{~A}, \mathrm{~B}$ 枠内 : $0.05 \mathrm{~mm}_{\text {。 }}$

\section{結果}

I 群（対照）では，DCO，腹側蝸牛神経核 (VCOa と VCOp), SPIV, MV, LAV で c-fos 陽 性細胞が散在性に認められたが，上前庭神経核 (SUV) では c-fos 陽性細胞は検出されなかった (図 2 )。

II群（110 dB SPL 負荷）では，DCO におい て c-fos 陽性細胞が I 群に比較して著明に増加 し，特徵的な帯域分布を示した（図 3 )。DCO の 帯域では，尾側端（切片 7-9）に外背側から内 腹側にかけて c-fos 陽性細胞を分布していた。 VCOa と VCOp では, c-fos 陽性細胞が観察され たが，DCO に比較して小数で，特徵的な集積を 認めなかった。

前庭神経核では，I群と比較して，c-fos 陽性 細胞数の変化はなく, 特徵的な局在はなかった。

III群（130 dB SPL 負荷）では，II群と比較し て DCO の c-fos 陽性細胞数がさらに増加し, 带 域分布はほとんど変化がなかった。VCOa と VCOpに颃いても，II群と比較して c-fos 陽性細 胞が増加した。

II群でほとんど c-fos 陽性細胞が観察されなか った前庭神経核では, SPIV と MV 中央部の境 界部（切片 7 と 8 ）, SPIV の吻側部外側（切片 8 と 9 ), LAV の尾側部内側の MV の境界部（切 片 9) に c-fos 陽性細胞の特徵的な分布が観察さ
れた。 SUV では， c-fos 陽性細胞は全く検出され なかった（図４）。

蝸牛神経核と前庭神経核で検出された c-fos 陽 性細胞数の計測結果を刺激条件毎に図 5 と図 6 に まとめて示した。DCO では, 刺激強度に依存し て c-fos 陽性細胞数の増加する傾向がみられた が，統計学的有意差はなかった。SPIV と MV では, II 群では I 群と比較して c-fos 陽性細胞数 の増加がみられず, III群では c-fos 陽性細胞数が 有意に増加した。

図 $7 \mathrm{~A}$ は本実験 $130 \mathrm{~dB}$ SPL 音刺激時, 冠状断 された c-fos 陽性細胞を背側から見るように前庭 神経核を再構築した図で，BとCはスナネズミ の球形囊神経と後半規管神経の中枢投射部位 ${ }^{21}$ の模式図，D と E はネコの内側前庭资髄路と外 側前庭水髄路の脳幹起始核部位 ${ }^{22)}$ の模式図であ る。これらの図より, 強大音刺激時ラット前庭神 経核内 c-fos 陽性細胞発現部位はスナネズミ球形 囊神経の中枢投射部位に近似していた。また，cfos 陽性細胞は内側前庭脊髄路の前庭神経核内起 始核部位とほほ一致して分布していたことを確認 した。

\section{考察}

本研究では, 強大音刺激時のラット脳幹内の蝸 牛神経核, 前庭神経核内 c-fos 陽性細胞発現様式 を検討した。その結果, 強大音刺激時 c-fos 陽性 
Equilibrium Res Vol. 59(4)

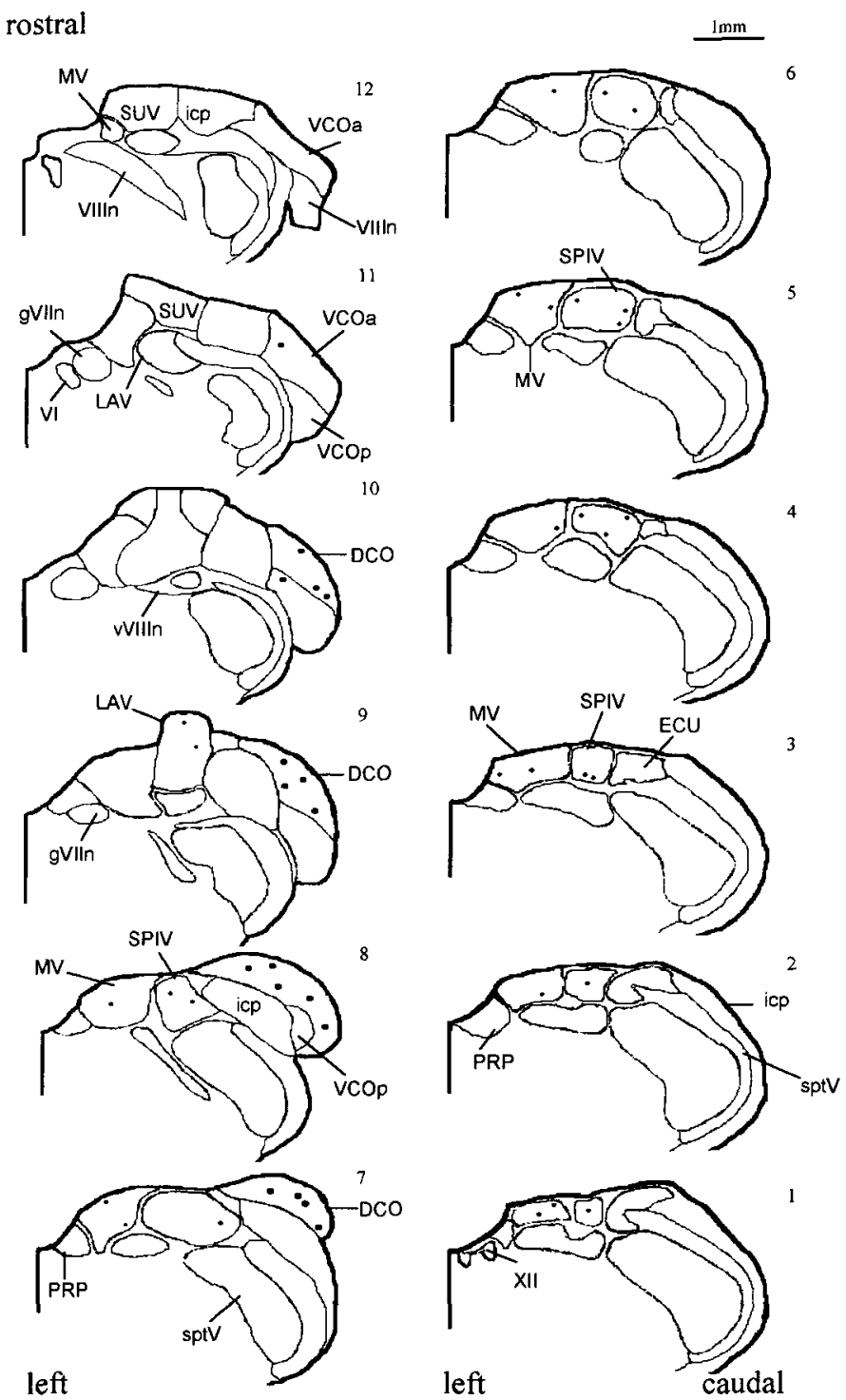

図 2 ラット43（I 群：対照）の右側の脳幹の c-fos 陽性紐胞の分布

図中の 1 枚の切片は，0.02 mm の厚さの切片10枚分を示しており，その10枚に認められた陽性紐胞全て を記入してある。VN の小さい点一つは 1 個，CN の大きい点一つは 5 個の陽性緗胞を示している。c-fos 陽性細胞は DN 和よびVN 飞散在性に分布したことを示す。

細胞は蝸牛神経核に打いては DCO で外背側から 内腹側にかけての帯域分布が観察され，前庭神経 核に㧤いて SPIV と MV の中央境界部や LAV の尾側部内側に集積が認められた。地た，SPIV， MV, LAV の前庭神経核諸核では最大音王刺激 時のみに c-fos 陽性細胞増加がみられ, DCO と 前庭神経核諸核との間には音刺激時の c-fos の発
現形式に明らかな差がみられた。

音刺激負荷時の $c$-fos マッピング法による蝸牛 神経核の研究は，これまでマウス23)，ラット 24)25)，モルモット26)，ネコ27) に打いて行われてき た。麻酔によるc-fos 陽性細胞数の減少，特徵的 な帯域の観察が不能となる報告がされて扣り ${ }^{26)}$; 本研究では無麻酔で実験を行った。音刺激の強度 
rostral
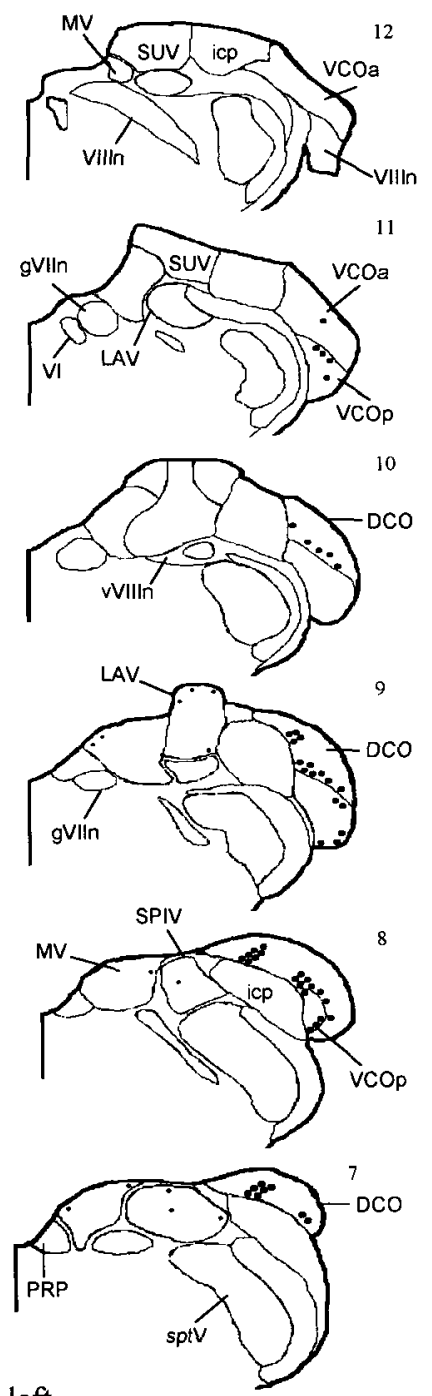

left

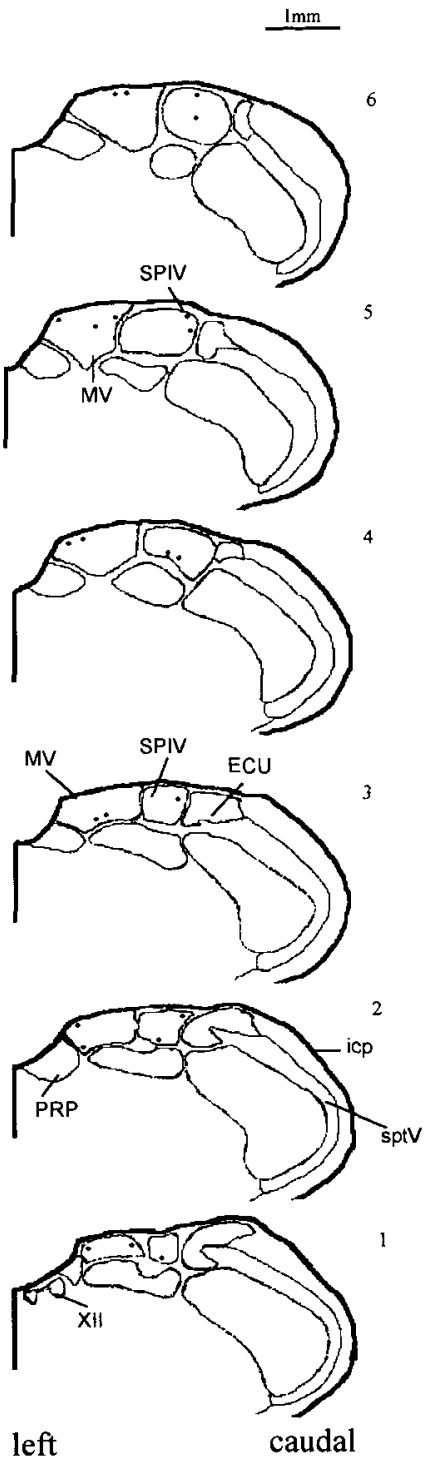

left

図 3 ラット47（群：110 dB SPL 負荷）の右側の脳幹の c-fos 陽性細胞の分布

DCO Kは c-fos 陽性細胞が外背側から内腹側にかけて特徵的な帯域を示した。VNでは特徵的な局在が なかった。

と蝸牛神経核内の c-fos 陽性細胞数の関係につい ては, Brown ら ${ }^{23)}$ がマウスで報告しており，6 $\mathrm{kHz}$ のトーンバーストによる 2 時間の音刺激の 結果，DCO をはじめとする蝸牛神経核の諸核の c-fos 陽性細胞数を計測した。その結果，刺激音 在を $15 \mathrm{~dB}$ SPL から $95 \mathrm{~dB}$ SPL まで $10 \mathrm{~dB}$ 毎に 上昇させていった場合，蝸牛神経核のいずれの核 でも音圧上昇と共に c-fos 陽珄細胞数は注涪線
性に数を増加すると報告した。一方ラットで は, Sato ら ${ }^{24)}$ がラットに $0.25 \mathrm{kHz}$ から $8 \mathrm{kHz}$ までの 3 周波数で純音を10-30分間負荷した場合，60 -70 dB SPL に比べ 80-90 dB SPL では DCO で c-fos 陽性細胞数が増加するが, VCOa VCOp では細胞数が増加しないと述べている。本研究で は，110 dB SPL 以上の音刺激において DCO の 他に VCOp でも増加が認められ, Brown ら ${ }^{23)} の$ 
Equilibrium Res Vol. 59(4)

rostral
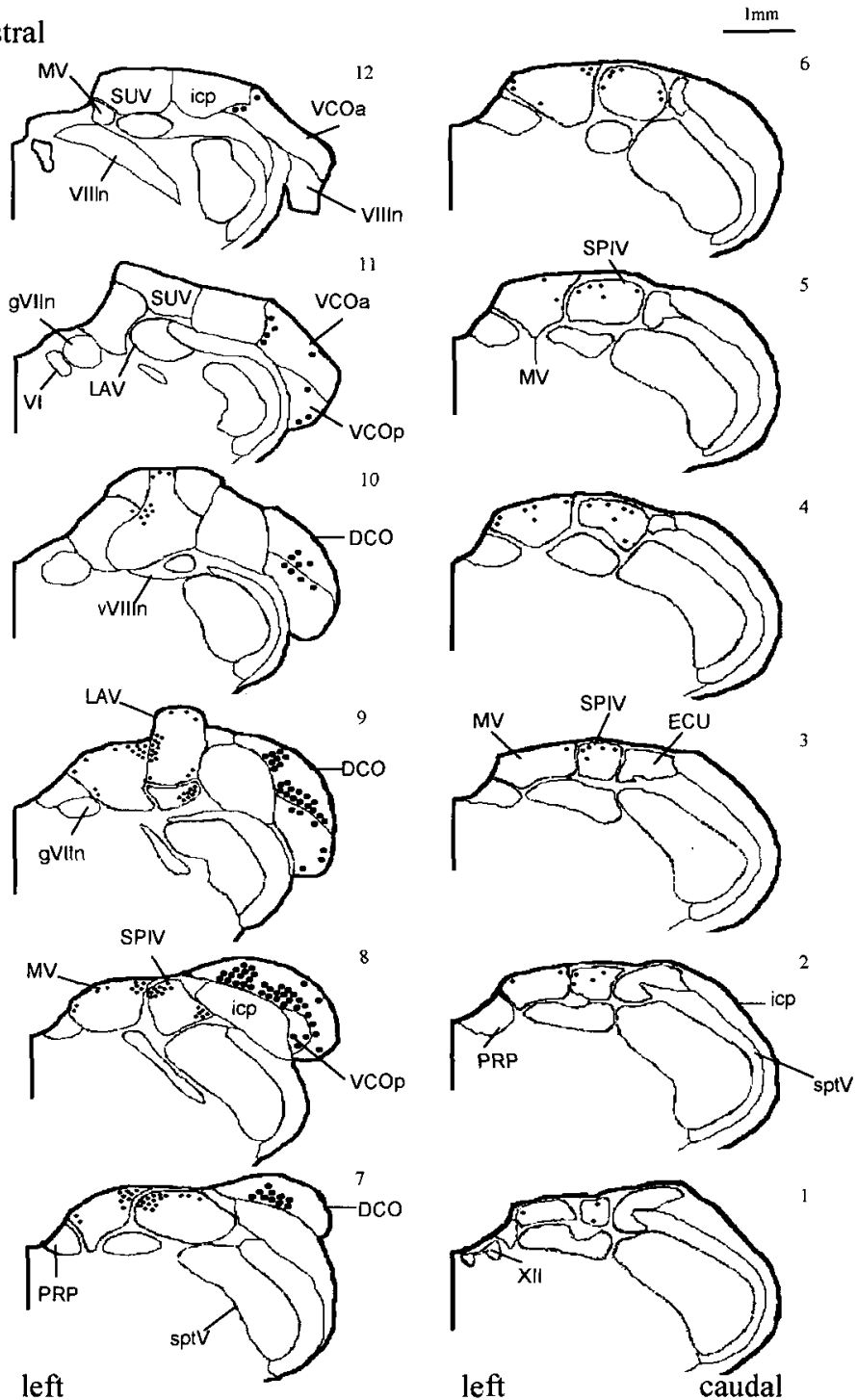

図 4 ラット53（III群：130 dB SPL 負荷）の右側の脳幹の c-fos 陽性細胞の分布

c-fos 陽性細胞は SPIV と MV 吻側の境界部, SPIV の吻側部外側, LAV の尾側部内側飞特徴的な分布 を示した。

結果と一致した。

電気生理学的研究28) と2-Deoxyglucose 法を用 いた研究 ${ }^{29)}$ から，ラット DCO ニューロンには 周波数局在性があることが報告されている。 DCO では，高い周波数に応答するニューロンは 背側部，低い周波数に応答するニューロンは腹側 部に局在すると考光られている。近年, c-fos マ ッピング法を用いた実験です周波数局在性につい
て検討されている。Rouiller ら ${ }^{30)}$ は，ラットに 1 $\mathrm{kHz}$ から $32 \mathrm{kHz}$ の 4 種類の周波数で $80 \mathrm{~dB} \mathrm{SPL}$ のトーンバースト刺激を 1 時間負荷した場合の c-fos 陽性細胞の局在を蝸牛神経核で調べ, DCO 内には尾側部之吻側部に 2 つの c-fos 陽性細胞の 帯域が認められ，後者のみが刺激周波数の上昇に より帯域の局在が腹側部から背側部へと恋华 1. と報告している。Sato ら ${ }^{24) は, ~ ラ ッ ト に ~} 0.25 \mathrm{kHz}$ 


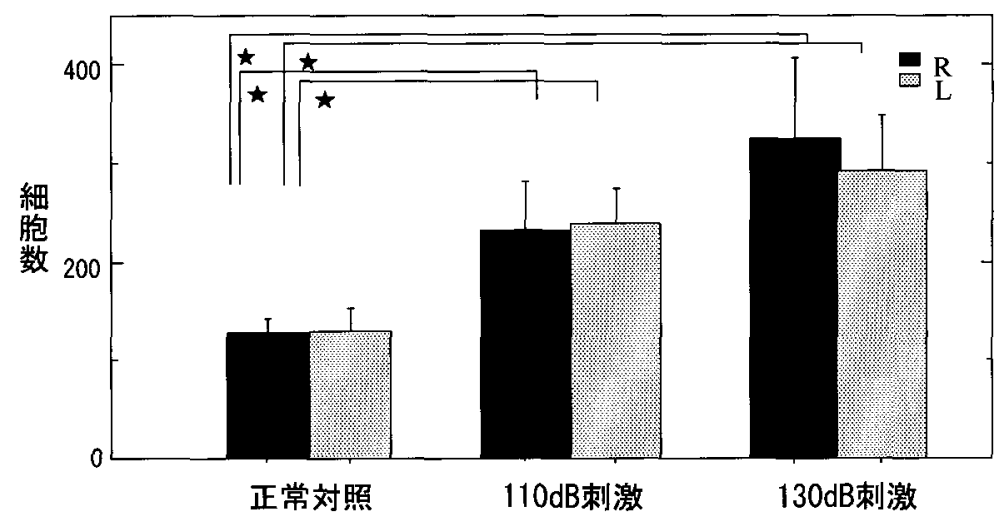

图 5 背側蝙牛神経核 (DCO) の c-fos 陽性細胞数の比較

太は $\mathrm{P}<0.05$ を示す。c-fos 陽性細胞は刺激強度に依存して增加する傾向がみられたが，統計的有意差が なかった。
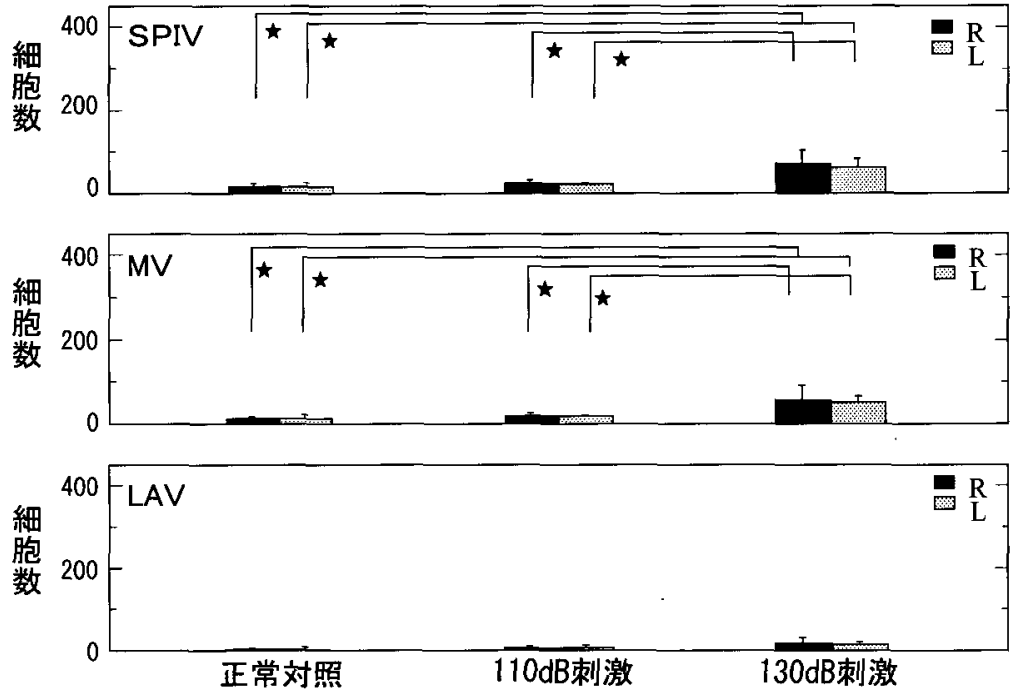

图 6 前庭神経核の c-fos 陽性細胞数の比較

SPIV とMV では, III群では c-fos 陽性細胞数が有意に增加したことを示す。

から $8 \mathrm{kHz}$ をでの 3 周波数で 60-90 dB SPL の 純音を10-30分間負荷した場合，吻側端ではなく 尾側部で周波数局在性が観察されたと指摘してい る。実験条件が異なっているが，本研究では Sato ら ${ }^{24)}$ と同様の帯域が尾側部で観察された。

前庭神経核に打いては，これまで迷路破壊術後 の前庭代償課程の研究 ${ }^{31) 32)}$ が c-fos マッピング法 を用いて主に行われてきたが，音刺激負荷時に前 庭神経核で c-fos 陽性細胞を観察したのは, Sato ら ${ }^{25)}$ の報告が唯一のものである。彼らは, 周波
数 $0.25 \mathrm{kHz}$ ，刺激音圧 $80 \mathrm{~dB}$ SPL，持続時間 30 分問の条件下でラットの SPIV と MV 内に c-fos 陽性細胞が出現することを報告したが，その集積 性の特徵について詳細な分析は行っていなかっ た。本研究により，周波数 $1 \mathrm{kHz}$ ，持続時間 60 分 間の条件下では，SPIV と MV の境界部扣よび LAV の内側部飞 $c$-fos 陽性細胞の集積は音刺激 強度が $130 \mathrm{~dB}$ SPL で認められることが初めて明 らかとなった。

末梢前庭器から前庭神経核への投射様式には特 

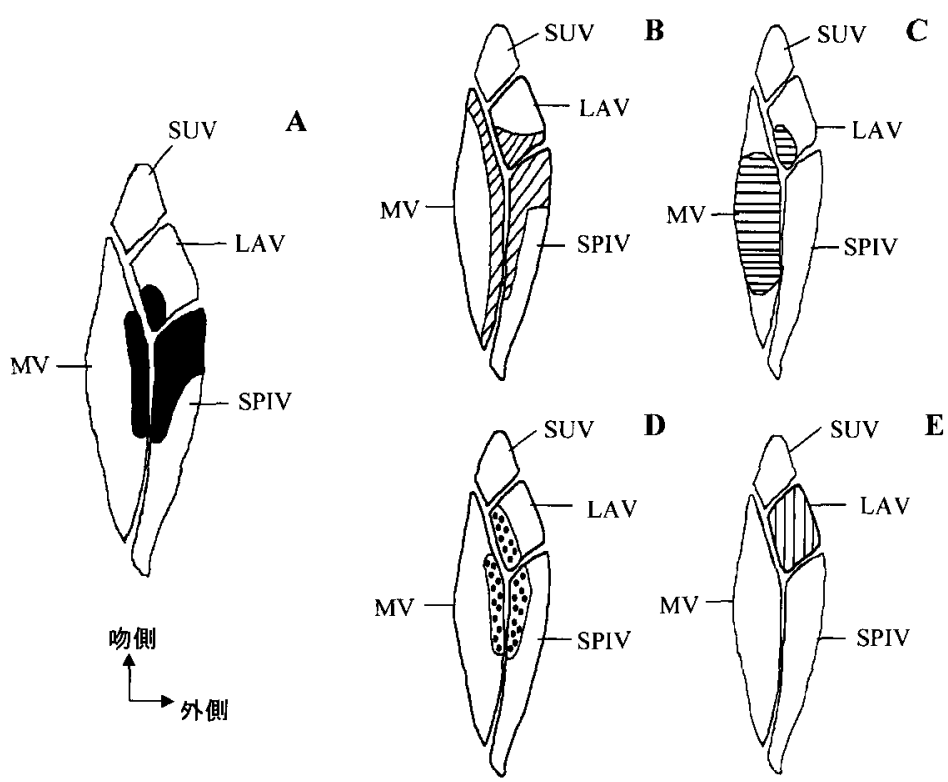

図 7 背側から見る前庭神経核

A: 冠状断を背側から見るよらに強大音刺激時ラット前庭神経核内 c-fos 陽性細胞分布様式, B: スナネズ ミ球形囊神経の中枢投射部位, C: スナネズミ後半規管神経の中枢投射部位, D: 内側前庭脊咀路の脳幹起 始核部位，E: 外側前庭脊㩆路の脳幹起始核部位。

徵的な局在がみられるため, c-fos マッピング法 による前庭神経核内での c-fos の発現様式から強 大音化応答する末梢前庭器の種類を推定すること が可能である。本研究で用いたラットでその投射 様式を調べた報告はないが，同じ絜歯類に属する スナネズミでは HRP 法により, 球形囊神経と後 半規管神経で前庭神経核への投射部位が調べられ ている21)。球形筒は MV の外背側部, SPIV の吻 側部背側部扣よび LAV の尾側部, 後半規管は MV の中間部括よび LAV の尾側部内背側部にと れぞれ神経線維の投射が確認されている。一方, 卵形蘘, 水平半規管呿よび前半規管からの投射に ついては, 䠛歯類では c-fos マッピング法あるい はHRP 法により検討した報告はなされていな い。本研究で明らかになった c-fos 陽性細胞の局 在は, SPIV と MV の境界部（MV の中間部外 背側部と SPIV の吻側部内背側部) や LAVの尾 側部内側部に認められ，これはスナネズミの球形 賈神経投射部位とほぼ一致していた。

また, 本研究では蝸牛神経核の c-fos 陽性細胞 数の增加が低音生 (110 dB SPL) で, 前庭神経核 では $130 \mathrm{~dB}$ SPL で初めて陽性細胞数が増加し, c-fos 陽性細胞発現に関して前庭神経核は蝸牛神 経核より閾值が高いことが明らかとなった。これ は電気生理学的に球形褧神経は蝸牛神経より音刺 激に対して高間值である報告9) 11) と一致してい た。これらの結果は, 球形艛が末梢前庭器ではす るが蝸牛と同様に強大音刺激により応答すること を示唆しているものと考えられた。

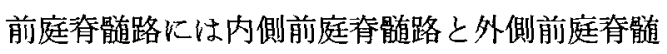
路の 2 種類があり，両者には種々の差があること が報告されている22)。図 $7 \mathrm{D}$ とに示したよら K, 内側前庭奇髄路は MV の中間部外側部, SPIV の吻側部内側部括よび LAV の内側部より 生じ, 雨側性に頸髄レベルまで神経線維投射が確 認されている。一方, 外側前庭脊顝路は, LAV 全体から生じ，同側性に腰髄レベルまで下降す る。本研究の結果では, 強大音刺激に応答する c-fos 陽性細胞の局在が MV, SPIV および LAV に括いて観察され, 内側前庭筒髄路の起始核の分 布にほぼ一致していた。この結果から, 前庭神経 核まで伝達された強大音刺激情報は, 主に内側前

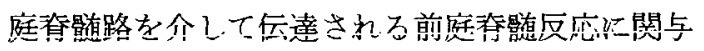
する可能性が高いことを示するのであった。 


\section{結 論 \\ ラットに特いて，c-fos マッピング法を用い，} 強大音に応答する脳幹尾側部ニューロンの局在を 前庭神経核と蝸牛神経核にて観察した。前庭神経 核では $130 \mathrm{~dB}$ SPL 刺激時のみに c-fos 陽性細胞 が有意に増加し, MV と SPIV の境界部や LAV の尾側部内側部に局在し, 球形哓神経の脳幹投射 部位扣よび内側前庭脊骨進路の脳幹起始核の部位と ほ注一致していた。これらの結果は，強大音に対 する前庭性反応の受容器が球形鉷であること, お よび球形䗒刺激により応答する前庭神経核ニュー ロンの神経活動が，主に内側前庭脊殉路を介して 伝達され前庭脊粗反射を誘発する可能性を示唆す るものであった。

\section{謝辞}

稿を終えるにあたり，ご指導，ご高閲を賜りま した富山医科薬科大学耳鼻咽喉科学教室渡辺行雄 教授，ならびに実験に関して直接ご指導を頂いた 同教室將積日出夫講師に深甚なる謝意を捧げま す。また実験手技に関して貴重な意見を頂いた富 山医科薬科大学精神神経科学教室鈴木道雄助教 授, 徳島大学医学部耳鼻咽喉科学教室の武田憲昭 教授, 扎よび大阪大学医学部耳鼻咽喉科学教室の 北原 糺先生, 実験全般に乱いてご協力を頂いた 富山医科薬科大学第一生理学教室の五十嵐勝美技 官に深く感謝致します。

\section{文 献}

1) Tullio P: Sulla funzione delle varie parti del labirinto acustico. Arch Ital Otol Rinol Laringol 35: 230-267, 1924

2) Erlich MA, Lawson W: The incidence and significance of the Tullio phenomenon in man. Otolaryngol Head Neck Surg 88: 630635,1980

3) Pillsbury III HC, Postma DS: The Tullio phenomenon, fistula test, and Hennebert's sign: clinical significance. Otolaryngol Clin North Am 16: 205-207, 1983

4) Fox EJ, Balkany TJ, Arenberg IK: The Tullio phenomenon and perilymph fistula. Otolaryngol Head Neck Surg 98: 88-89, 1988

5) Dickson EDD, Chadwick DL: Observations on disturbances of equilibrium and other symptoms induced by jet-engine noise. J
Laryngol Otol 65: 154-165, 1951

6) Colebatch JG, Halmagyi GM: Vestibular evoked potentials in human neck muscles before and after unilateral vestibular deafferentation. Neurology 42: 1635-1636, 1992

7) Colebatch JG, Halmagyi GM, Skuse NF: Myogenic potentials generated by a clickevoked vestibulocollic reflex. J Neurol Neurosurg Psychiatry 57: 190-197, 1994

8 ）竹森節子：耳-生理 (平衡). 沢木修二, 設楽 哲也，野村恭也編. 臨床耳鼻咽喉科学 1 基 礎編. 116-152頁, 中外医学社, 東京, 1980

9) Cazals Y, Aran JM, Erre JP, et al: “Neural” responses to acoustic stimulation after destruction of cochlear hair cells. Arch Otorhinolaryngol 224: 61-70, 1979

10) Cazals Y, Aran JM, Erre JP, et al: Acoustic responses after total destruction of the cochlear receptor: brainstem and auditory cortex. Science 210: 83-86, 1980

11) Cazals Y, Aran JM, Erre JP: Frequency sensitivity and selectivity of acoustically evoked potentials after complete cochlear hair cell destruction. Brain Res 231: 197-203, 1982

12) Murofushi T, Curthoys IS, Gilchrist DP: Response of guinea pig vestibular nucleus neurons to clicks. Exp Brain Res 111: 149152, 1996

13) Sagar SM, Sharp FR, Curran T: Expression of c-fos protein in brain: Metabolic mapping at the cellular level. Science 240: 1328-1331, 1988

14) Dragunow M, Faull R: The use of $c-f o s$ as a metabolic marker in neuronal pathway tracing. J Neurosci Methods 29: 261-265, 1989

15) Hunt SP, Pini A, Evan G: Induction of c-foslike protein in spinal cord neurons following sensory stimulation. Nature 328: 632-634, 1987

16) Lenhardt ML: Preyer reflex in jaundiced rats: central auditory effects. J Aud Res 25: 161-166, 1985

17) Francis RL: The preyer reflex audiogram of several rodents, and its relation to the "abso- 
lute" audiogram in the rat. J Aud Res 19: 217-233, 1979

18) Hamba $M$, Muro $M$, Hiraide $T$, et al: Expression of c-fos-like protein in the rat brain after injection of interleukin-l-bete into the gingiva. Brain Res Bull 34: 61-68, 1994

19) Hsu SM, Rain L, Fanger H: Use of avidinbiotin-peroxidase complex (ABC) in immunoperoxidase techniques: A comparison between $A B C$ and nulabeled antibody (PAR) procedures. J Histochem Cytochem 59: 577-580, 1981

20) Swanson LW: Brain maps: Structure of the rat brain. pp 53-64, Elsevier, 1992

21) Kevetter GA, Perachio AA: Distribution of vestibular afferents that innervate the sacculus and posterior canal in the gerbil. J Comp Neurol 254: 410-424, 1986

22) Wilson VJ: Physiological pathways through the vestibular nuclei. Int Rev Neurobiol 15: 27-81, 1972

23) Brown MC, Liu TS: Fos-like immunoreactivity in central auditory neurons of the mouse. J Comp Neurol 357: 85-97, 1995

24) Sato K, Houtani $T$, Ueyama T, et al: Mapping of the cochlear nucleus subregions in the rat with neuronal Fos protein induced by acoustic stimulation with low tones. Neurosci Lett 142: 48-52, 1992

25) Sato $K$, Houtani $T$, Ueyama $T$, et al: Identification of rat brainstem sites with neuronal fos protein induced by acoustic stimulation with pure tones. Acta Otolaryngol Suppl (Stockh) 500: 18-22, 1993

26) Cody AR, Wilson W, Leah J: Acoustically activated $\mathrm{c}$-fos expression in auditory nuclei of the anaesthetised guinea pig. Brain Res 728: 72-78, 1996

27) Adams JC: Sound stimulation induces fosrelated antigens in cells with common morphological properties throughout the auditory brainstem. J Comp Neurol 361: 645-668, 1995

28) Kaltenbach JA, Lazor J: Tonotopic maps obtained from the surface of the dorsal cochlear nucleus of the hamster and rat. Hear Res 51: 149-160, 1991

29) Ryan AF, Furlow $Z$, Woolf NK, et al: The spatial representation of frequency in the rat dorsal cochlear nucleus and inferior colliculus. Hear Res 36: 181-190, 1988

30) Rouiller EM, Wan XST, Moret V, et al: Mapping of $\mathrm{c}$-fos expression elicited by pure tones stimulation in the anditory pathways of the rat, with emphasis on the cochlear nucleus. Neurosci Lett 144: 19-24, 1992

31) Kitahara $T$, Takeda $N$, Saika $T$, et al: Role of the flocculus in the development of vestibular compen-sation: Immunohistochemical studies with retrograde tracing and flocculec-tomy using fos expression as a marker in the rat brainstem. Neuroscience 76: 571580,1997

32) Kitahara T, Takeda N, Saika T, et al: Effects of MK801 on Fos expression in the rat brainstem after unilateral labyrinthectomy. Brain Res 700: 182-190, 1995

$\left(\begin{array}{l}\text { 原稿到着 : 平成11年11月17日 } \\ \text { 別刷請求先 : 張 瑞麗 } \\ \text { T930-0194 富山市杉谷2630 } \\ \text { 富山医科薬科大学耳鼻咽喉科学教室 } \\ \text { E-mail: g6410108@ms.toyama-mpu.ac.jp }\end{array}\right)$

